\title{
THE COURT OF JUSTICE OF THE EUROPEAN UNION: INTERNATIONAL OR DOMESTIC COURT?
}

\author{
Jed Odermatt*
}

\begin{abstract}
This article discusses how the Court of Justice of the European Union (CJEU) deals with international law issues. While the EU and the Court itself are often presented as being 'friendly' towards international law, recent cases have shown a trend towards a more guarded approach by the Court. The article first examines recent literature on the CJEU's relationship with international law which demonstrates an oscillation between 'openness' towards international law and an approach that emphasises the autonomy of the EU legal order. It then discusses what rules exist to guide the Court in determining its relationship with international law. To what extent do the EU Treaties, the legal traditions of the Member States or international law itself determine how the CJEU should deal with international law issues? The next part examines how the CJEU has dealt with international law in practice. The CJEU has progressively developed tools to limit the effect of international law, as it attempts to strike a balance between respect for international law and the need to safeguard the integrity of the EU legal order. It discusses some recent cases where the CJEU dealt with key international law issues in order to demonstrate how this relationship is shaped in practice. The final part seeks to understand why the Court seems to oscillate between an open and a closed approach to international law. It is posited that this can partly be explained by whether the Court is acting in its capacity as an international or a domestic court.
\end{abstract}

\section{Keywords}

Court of Justice of the European Union, International Law, European Law, EU Legal Order, International Court, Domestic Court, Kadi, Mox Plant, Air Transport Association of America, Brita, Hungary v Slovak Republic, Diakité

\section{Introduction}

If the EU perceives of itself as a uniquely internationally engaged entity, and as a political system founded on the idea of transnational legal and political cooperation, we would be inclined to expect that its Court of Justice would reflect something of this internationalist orientation too.

\footnotetext{
PhD Candidate, Leuven Centre for Global Governance Studies/Institute for International Law.

1 G de Búrca, 'After the EU Charter of Fundamental Rights: The Court of Justice as a Human Rights Adjudicator?' (2013) 20 Maastricht JECL 168, 183.
}

Copyright $\odot$ the Author(s).

This work is licensed under a Creative Commons Attribution-NonCommercial-NoDerivs 3.0 License. 
De Búrca alludes to a supposed paradox that underlies the EU's relationship with international law. On the one hand, the EU founding treaties state that the EU shall contribute to the 'strict observance and the development of international law' and the EU has for decades presented itself as a good global citizen which seeks to respect international law. On the other hand, recent case law of the Court of Justice of the European Union (CJEU or Court) has often stressed the autonomy of the EU legal order, demonstrating what may be considered to be a less 'friendly' attitude towards international law. The purpose of this contribution is to further understand this apparent paradox.

The first part briefly examines recent literature that has described the CJEU's relationship with international law. It then discusses what rules exist to guide the Court in determining its relationship with international law. To what extent do the EU Treaties, the legal traditions of the Member States or international law itself determine how the CJEU should deal with international law issues? The next part examines how the CJEU has dealt with international law in practice. The CJEU has progressively developed tools to limit the effect of international law, as it attempts to strike a balance between respect for international law and the need to safeguard the integrity of the EU legal order. It discusses some recent cases where the CJEU dealt with key international law issues in order to demonstrate how this relationship is shaped in practice. The final part tries to understand why the Court seems to oscillate between an open and a closed approach to international law. It is posited that this can partly be explained by whether the Court is acting in its capacity as an international or a domestic court.

\subsection{Oscillation between 'Open' and 'Closed'}

There is an ever-expanding literature focusing on the EU's relationship with international law. This tells strikingly different stories about the CJEU's attitude. Whereas some scholars describe the EU legal order and the CJEU as 'völkerrechtsfreundlich, ${ }^{2}$ others view the Court's attitude, particularly since the Kadi ${ }^{3}$ judgment, as one that is much less open to international law. The dominant view is that the CJEU is generally open to international law but retains the prerogative to determine how and under what circumstances international law has an influence

2 E Cannizzaro, 'Neo-monism of the European Legal Order', in E Cannizzaro, P Palchetti \& R A Wessel (eds), International Law as Law of the European Union (2011) 57.

3 Joined Cases C-402/05 P \& C-415/05 P, Yassin Abdullah Kadi \& Al Barakaat International Foundation v Council and Commission [2008] ECR I-6351. 
in the EU legal order. In a recent book examining the relationship between the $\mathrm{EU}$ and international law the editors summarise the position:

Although openness to international law is the prevalent vision, whether international law should function in the EU internally depends on the blessing of the Union, which can also be withheld, should it contradict the EU's policy, objectives, rationale or principles. $^{4}$

Some writers have pointed out that the Court has generally taken an 'international-law-friendly approach, ${ }^{5}$ asserting that the CJEU's case law is 'particularly friendly towards international law'. ${ }^{6}$ Kaddous writes that '[i]n recent years the Court has taken a very open approach to the effects of international agreements within the EU legal order.7 Regarding its approach to treaties, Mendez argues that the CJEU has taken a 'maximalist' approach. ${ }^{8}$ Similarly, Petersen contrasts the CJEU's approach to international law with the 'sovereignty paradigm' of the US Supreme Court, arguing that the CJEU 'primarily adopts an internationalist standpoint.' Regarding the reception of international law into the EU legal order, Martines states that the EU order 'appears rather permeable to international law provisions. ${ }^{10}$

Recent scholarly literature, however, has pointed the CJEU's 'judicial recalcitrance $^{\text {11 }}$ towards incorporating international law norms. Klabbers, for example,

${ }^{4}$ D Kochenov \& F Amtenbrink (eds), The European Union's Shaping of the International Legal Order (2014) 5.

5 P J Kuijper, 'Customary International Law, Decisions of International Organisations and Other Techniques for Ensuring Respect for International Legal Rules in European Community Law', in J Wouters, A Nollkaemper \& E De Wet (eds), The Europeanisation of International Law (2008) 29.

${ }^{6}$ R Uerpmann-Wittzack, 'The Constitutional Role of International Law', in A Von Bogdndy \& J Bast (eds), Principles of European Constitutional Law (2 ${ }^{\text {nd }}$ edn, 2010) 138, 143.

7 C Kaddous, 'Effects of International Agreements in the EU Legal Order', in M Cremona \& B de Witte (eds), EU Foreign Relations Law: Constitutional Fundamentals (2008) 311.

${ }^{8}$ M Mendez, "The Legal Effect of Community Agreements: Maximalist Treaty Enforcement and Judicial Avoidance Techniques' (2010) 21 EJIL 83, 88.

9 N Petersen, 'The Reception of International Law by Constitutional Courts through the Prism of Legitimacy'(2012) 72 ZaöRV 223, 239.

${ }^{10}$ F Martines, 'Direct Effect of International Agreements of the European Union' (2014) 25 EJIL 129,135 .

${ }^{11}$ F Casolari, 'Giving Indirect Effect to International Law within the EU Legal Order: The Doctrine of Consistent Interpretation', in E Cannizzaro, P Palchetti \& R A Wessel (eds), International Law as Law of the European Union (2011) 395. 
posits that the CJEU 'is highly reluctant to give any effect to international law.' ${ }^{12}$ He challenges the assumption of many scholars that the EU is 'friendly' towards international law:

This position has no doubt contributed to the image of the EU as an actor that is friendly disposed towards international law, but the image is deceptive: the EU is friendly disposed towards EU law, and while it may have been fashionable to regard EU law as an emanation of international law, this is no longer habitually done. The fact that EU law prescribes monism with respect to its own domestic effect is understandable and has in all likelihood contributed greatly to the longevity and success of the EU, but is not based on a particularly friendly attitude towards international law. ${ }^{13}$

The CJEU's relationship with international law is sometimes discussed in terms of adopting a monist or dualist approach: '[d]epending on its perspectiveand not on a different standpoint of the observer-the ECJ applies a monistic doctrine relating to its Member States and a dualistic doctrine relating to international law, two completely diverging doctrines.'.

It is often stated that the CJEU's approach to international law is a 'monist' one. ${ }^{15}$ However, as Eckes argues, '[i]n recent landmark cases such as Kadi or Intertanko, the Court of Justice's approach to international law appears to be more "dualist" in that it restricts the effects of international law within the European legal order. ${ }^{16}$ De Búrca also argued that in Kadi the CJEU adopted 'a sharply dualist tone in its approach to the international legal order and to the relationship between EC law and international law.' ${ }^{17}$

The Court's approach to international law, according to the literature, seems to oscillate between 'open' and 'closed', 'friendly' and 'unfriendly'. Both

12 J Klabbers, The European Union in International Law (2012) 77.

13 Ibid, 71.

${ }^{14}$ L Kirchmair, "The "Janus Face" of the Court of Justice of the European Union: A Theoretical Appraisal of the EU Legal Order's Relationship with International and Member State Law' (2012) 4 Goettingen JIL 677, 679.

${ }^{15}$ K Lenaerts, 'Droit International et Monism de l'Ordre Juridique de l’Union' (2010) Revue de la Faculté de Droit de l'Université de Liège 505.

${ }^{16}$ C Eckes, 'International Law as Law of the EU: The Role of the ECJ', in E Cannizzaro, P Palchetti \& R A Wessel (eds), International Law as Law of the European Union (2011).

${ }^{17}$ G de Búrca, 'The European Court of Justice and the International Legal Order After Kadi' (2009) 51 Harvard ILJ 1, 2. 
international law and EU law scholars have noted that the CJEU's approach to international law seems to have shifted over time. It is perhaps an understatement to say that " $t$ ] he case law of the ECJ on the effect of decisions of international authority within the EU legal system is not entirely homogenous. ${ }^{18}$ What can explain this? The problem with terms like 'openness' and 'friendliness' to describe the CJEU's approach to international law is that they tend to obscure what is in fact a much more complex relationship. It may be better to understand it as multiple relationships. At times, the Court's approach is 'closed' or 'dualist' because it is operating as a domestic constitutional court, seeking to find a balance between respect for international law and the need to safeguard the autonomy of the EU legal order. In other instances, the EU is much more open to international law because it employs international law as a tool to resolve legal issues, much more like an international court.

Allain notes that '[ $\mathrm{f}] \mathrm{ew}$ would care to characterise the European Court of Justice as an international court. ${ }^{19}$ This is because, while the CJEU is an 'international' court in the sense that it is established by Member States by an international treaty, the Court fulfils a role that is much closer to that of a national/federal constitutional court. In this contribution, the term 'international' or 'domestic' are used to describe the role that the Court plays in a given case, rather than the nature of the Court as such. When it acts as an international court, the CJEU interprets and applies international law to resolve disputes. It acts as a domestic (constitutional) court when it determines how international law can have effect in the EU legal order and the extent to which international law may be used as a yardstick to judge the validity of EU acts. It is argued that the Court is much more open to international law when it fulfils the former role and more guarded when it fulfils the latter. The purpose of this contribution is to go further than the one-dimensional narrative of international law friendliness towards developing an understanding of the multiple relationships that exist. How does the Court's role as an international or domestic court shape its approach to international law?

\footnotetext{
${ }^{18}$ Petersen, above n 9, 248.

${ }^{19}$ J Allain, 'The European Court of Justice is an International Court' (1999) 68 Nordic JIL 249.
} 


\section{Developing the CJEU's Approach to International Law Issues}

It is generally accepted that the CJEU is free to determine how it deals with international law. This is in line with the understanding that on the question of how domestic legal orders give effect to international legal norms, international law is agnostic. The constitutional systems of states may require international law to be transposed into domestic legislation before it is given effect or they may apply international law directly. Similarly, the CJEU is still in the process of determining how, and under what conditions, international law should be given effect within the EU legal order. In determining the contours of this relationship the CJEU may be guided by the EU Treaties, the legal systems of the Member States and by international law itself.

\subsection{The EU Treaties and International Law}

Klabbers notes that the TEU (nor any of the other relevant foundational treaties) says nothing whatsoever about the effect of international law within the "internal" legal order of the EU. ${ }^{20}$ While it is true that the EU Treaties do not contain specific clauses specifying how international law is to be dealt with, the Treaties are not entirely silent on the issue of international law and thus can be used as a starting point for the Court.

The EU Treaties demonstrate a commitment to the respect for international law and multilateralism. Article 3(5) TEU states that the Union 'shall contribute [...] to the strict observance and the development of international law'. The Court has interpreted this to mean that 'when it adopts an act, it is bound to observe international law in its entirety, including customary international law. ${ }^{21}$ Article 21(1) TEU provides that the Union's 'action on the international scene' is to be guided by numerous principles, including the 'respect for the principles of the United Nations Charter and international law.'22 Respect for international law is referred to as one of the EU principles that inspired [the Union's] own creation $^{23}$ on the same level as principles such as democracy, the rule of law and

\footnotetext{
${ }^{20}$ Klabbers, above n 12, 72 .

${ }^{21}$ Case C-366/10, Air Transport Association of America and Others $v$ Secretary of State for Energy and Climate Change [2011] ECR I-1133, para 101 (ATAA).

${ }^{22}$ Consolidated Version of the Treaty on European Union [2012] OJ C 326/13 (TEU), Art 21(1); Case C-366/10, ATAA [2011] ECR I-1133, Opinion of Advocate General Kokott, para 43.

${ }^{23}$ TEU Art 21(1).
} 
human rights and fundamental freedoms. It also states that the EU must 'promote multilateral solutions to common problems, in particular in the framework of the United Nations' and 'promote an international system based on stronger multilateral cooperation and good global governance. ${ }^{24}$ One of the goals of the EU's external action is to 'consolidate and support democracy, the rule of law, human rights and the principles of international law'. ${ }^{25}$ This applies not only to 'the Union's external action' but also to 'the external aspects of its other policies. ${ }^{26}$

It is evident therefore that the respect for international law, particularly with regard to the UN and the multilateral system of governance, is given a prominent place within the Treaties. One could argue, however, that these statements are more of a political nature to guide the EU's external action rather than its constitutional relationship with international law. However, it is submitted that the respect for international law as enshrined in the EU Treaties, can have an effect on the Court's approach to international law issues. The Court should attempt, as far as it is possible, to avoid divergences between the approach of the Court and the other EU organs. ${ }^{27}$ It can view the respect for international law not as merely a foreign policy goal, but also as a constitutional principle that can be used to guide the CJEU. Such an overarching approach, founded in EU constitutional law, may help the Court develop a more consistent and principled approach when dealing with international law questions.

\subsection{International Law and the EU Legal Order}

In determining its relationship with international law, the Court can be guided by the EU Treaties. But can the CJEU also be guided by general international law? It is accepted that the CJEU can determine its own relationship with international law because it is a Court within a domestic legal order, one that applies and interprets EU law in a similar way to other domestic courts. Moreover, as noted above international law does not dictate the precise method by which it is to be given effect within the legal orders of its subjects. As Denza states:

International law does not itself prescribe how it should be applied or enforced at the national level. It asserts its own primacy over

\footnotetext{
24 TEU Art 21(1) second para, 21(2)(f).

25 TEU Art 21(2)(b) (emphasis added).

26 TEU Art 21(3).

${ }^{27}$ See J Wouters, J Odermatt \& T Ramopoulos, 'Worlds Apart? Comparing the Approaches of the European Court of Justice and the EU Legislature to International Law', in M Cremona \& A Thies, The European Court of Justice and External Relations: Constitutional Challenges (2014).
} 
national laws, but without invalidating those laws or intruding into national legal systems, requiring a result rather than a method of implementation. National constitutions are therefore free to choose how they give effect to treaties and to customary international law. ${ }^{28}$

Yet, the CJEU not only functions as a domestic court, but also as an international one. It is the judicial organ of a regional organisation established by treaties according to international law. This way the CJEU may decide to develop an approach to international law that recognises and acknowledges the fact that it is an international legal body. This approach does not contradict the case law, beginning with Van Gend en Loos, ${ }^{29}$ which asserts that international law is not determinative in applying and interpreting the EU Treaties, since EU Member States have developed 'a new legal order of international law. ${ }^{30}$ According to this approach, the CJEU would still be capable of determining how international law is given effect in the EU legal order. However, when choosing between adopting a sovereigntist or an internationalist approach to an issue, the EU's nature as an international organisation should lead to adopting the latter. This is because the CJEU is more than a domestic court and its judgments have a wider effect on the development of international law generally. International law scholarship views the CJEU as an influential judicial body in the development of international law:

Clearly decisions of judicial organs, such as the International Court of Justice and the Court of Justice of the European Union, contribute to the development of the law of treaties including principles of interpretation as well as general international law. The specialized function of such bodies may naturally limit their contribution to the latter. $^{31}$

Such an approach seems to be in line with the EU founding treaties, which proclaim the EU to be an international organisation founded on principles including the respect for international law. It would also help remove contradictions between the EU's internationalist rhetoric, which promotes and embraces international law, and its more sovereigntist jurisprudence, which sometimes

\footnotetext{
${ }^{28}$ E Denza, 'The Relationship between International and National Law', in M Evans (ed) International Law ( $3^{\text {rd }}$ edn, 2010) 411.

${ }^{29}$ Case C-26/62, Van Gend en Loos v Nederlandse Administratie der Belastingen [1963] ECR1 (Van Gend en Loos).

${ }^{30}$ Ibid, para 12.

${ }^{31}$ J Crawford, Brownlie's Principles of Public International Law $\left(8^{\text {th }}\right.$ edn, 2012) 194.
} 
views international law as a threat to the integrity and autonomy of the EU legal order. The Court should see itself as something more than a domestic court, i.e. also one that contributes to the development of international law.

\section{International Law before the CJEU: Multiple Approaches}

The previous section argued that the Court is free to decide its relationship with international law but that it should be guided by the EU Treaties and by its nature as an international court. The CJEU is very much still in a process of shaping the contours of its relationship with international law. As the EU becomes ever more active on the international stage, the interactions between the EU and international legal orders have become more common and more complex. There is a tendency, however, for international lawyers to attach significance to landmark cases such as Kadi and Mox Plant and to view the CJEU's sovereigntist approach as a threat to the universal nature of the international legal order. However, it is argued that these cases are not broadly indicative of an approach that is developing in the case law.

One of the reasons why a one-dimensional narrative that describes the 'openness' of the Court to international law is inadequate is that the Court confronts international law issues in a variety of circumstances. Its approach to international law issues depends often on the function or role that the Court is playing. Much of the literature on the CJEU's relationship with international law examines the issue of how international law is given direct effect within the EU legal order. But before the Court can determine what effect to give to international law principles, it first must determine (i) whether the rule invoked is indeed a source of international law, and (ii) whether it is binding upon the Union.

On the first question, the test is usually straightforward since in many cases the rule being invoked is enshrined in a treaty. However, the issue is more complex when rules of customary international law are being invoked. The Court has given little guidance regarding how it determines the existence of a customary rule. In Hungary $v$ Slovakia, the Court relied in part on rules of customary international law but did not elaborate on how it identifies these rules. $^{32}$ In $A T A A$, the Court gives a little more insight. It noted, for example, that the customary law principles being relied upon are enshrined in Article 1

\footnotetext{
${ }^{32}$ Case C-364/10, Hungary v Slovak Republic [2012] nyr, para 46 (Hungary v Slovakia): ‘[O]n the basis
} 
of the Chicago Convention, ${ }^{33}$ Article 2 of the 1958 Geneva Convention on the High Seas, ${ }^{34}$ and the United Nations Convention on the Law of the Sea, ${ }^{35}$ and it referred also to the jurisprudence of the International Court of Justice and the Permanent Court of International Justice. ${ }^{36}$

The second issue is whether the norm invoked is binding upon the Union. Again, in cases of treaties to which the EU is a party, the answer is generally straightforward. In some cases, the CJEU may be asked to apply a treaty to which the EU is not a party but all the EU Member States are. The Court has found that the treaty obligations of the Member State can be transferred to the EU via the theory of 'functional succession'. However, the CJEU has been highly reluctant to find that such a succession has taken place, limiting it to instances where there has been a full transfer of powers to the EU level. ${ }^{37}$ In other cases, the principle invoked may not be binding upon the Union but may nevertheless represent international 'soft law'. The Court may, for example, invoke a norm that is developed at the international level but is not strictly binding. It has done so regarding decisions of international bodies which, although not having binding legal effect, may nevertheless be persuasive in the Court's reasoning. ${ }^{38}$ There is a proliferation of international norms including guidelines, standards, best practices, and decisions of international bodies. The Court has not yet developed a consistent approach in deciding what effect to give these non-binding instruments in the EU legal order.

In many cases the Court will determine whether a rule of international law that is binding upon the Union should be given legal effect in the EU legal order. Much of the literature examining the CJEU's approach to international law relates to this very issue. The issue of direct effect:

goes to the heart of the constitutional architecture of the EU where a balance is to be found between openness to international law, legal

of customary rules of general international law [...] the Head of State enjoys a particular status in international relations which entails, inter alia, privileges and immunities'.

${ }^{33}$ Case C-366/10, ATAA [2011] ECR I-1133, para 104.

${ }^{34}$ Ibid.

${ }^{35}$ Ibid.

${ }^{36}$ Ibid.

${ }^{37}$ See J Odermatt, 'Case C-366/10, Air Transport Association of America and Others v. Secretary of State for Energy and Climate Change' (2013) 20 Columbia JEL 143.

${ }^{38}$ See J Wouters \& J Odermatt, 'Norms Emanating from International Bodies and Their Role in the Legal Order of the European Union', in R A Wessel \& S Blockmans (eds), Between Autonomy and Dependence: The EU Legal Order under the Influence of International Organisations (2012) 47. 
certainty, and compliance with international obligations assumed by the EU, and the integrity of the constitutional principles which define its identity. ${ }^{39}$

Although the Court has determined that international law, including both treaty and customary international law, ${ }^{40}$ is binding upon the Union from the moment it enters into force, ${ }^{41}$ it has established certain rules to determine the circumstances under which rules of international law may be given effect. The Court acknowledges that international law applies to the EU but it is much more restrictive when it comes to actually giving it legal effect in specific cases. In cases where international law is used to challenge the validity of EU legislation, for example, the Court has developed strict criteria to determine whether international law may be used as a basis for review. The Court must determine whether a treaty is directly applicable and directly effective. It first looks at the 'nature and broad logic' of the treaty 'in particular [...] its aim, preamble and terms ${ }^{\prime 42}$ to determine whether it precludes it from being used as a standard of review. It then turns to whether the norm invoked is 'unconditional and sufficiently precise' in order for it be used to challenge the validity of the EU act. $^{43}$

The Court has a well-developed line of case law dealing with the direct effect of international treaties in the EU legal order. ${ }^{44}$ It has also begun to develop an approach towards the direct effect of customary international law. ${ }^{45}$ Yet, the Court's relationship with international law goes beyond direct effect. For instance, the Court has turned to international law as a tool in treaty interpretation. It may, for instance, employ principles of the 1969 Vienna Convention on the Law of Treaties (VCLT) or look towards international law instruments in order to find the meaning of a certain term. When using it as a tool, the Court seems to be much more willing to deal with international law.

\footnotetext{
${ }^{39}$ Martines, above $\mathrm{n} 10,131-2$.

${ }^{40}$ Case C-162/96, A Racke GmbH \& Co v Hauptzollamt Mainz [1998] ECR I-3655, para 52 (Racke).

${ }^{41}$ Case C 533/08, TNT Express Nederland BV v AXA Versicherung AG [2010] ECR I-4107, para 60.

${ }^{42}$ Case C-308/06, International Association of Independent Tanker Owners (Intertanko) and others $v$ Secretary of State for Transport [2008] ECR I-4057, para 54 (Intertanko).

${ }^{43}$ Case C-366/10, ATAA [2011] ECR I-1133, para 74.

${ }^{44} \mathrm{~K}$ Lenaerts, 'Direct Applicability and Direct Effect of International Law in the EU Legal Order', in I Govaere, E Lannon, P Van Elsuwege \& S Adam (eds), The European Union in the World: Essays in Honour of Marc Maresceau (2014) 45.

${ }^{45}$ Case C-366/10, ATAA [2011] ECR I-1133.
} 
Even where a treaty is not binding on the EU or is found not to have direct effect, the Court has noted that it may nevertheless be bound to interpret EU law 'in the light of' international law. The Court has acknowledged the principle of 'consistent interpretation', which stems in part from the EU's duty to respect international agreements under Article 216(2) TFEU. It has been suggested that the application of this principle would be 'a useful means for the removal of divergences between two or more norms without resorting to the modification of those norms through the legislative process. ${ }^{46}$ The precise scope of this duty remains unclear, and there are only few instances of the Court applying the doctrine of consistent interpretation in practice. Moreover, although the CJEU has employed international law as a tool for interpretation, the CJEU retains the prerogative to give an autonomous, 'European' meaning to a certain term.

The CJEU's relationship with international law therefore involves much more than the issue of direct effect. Focusing on this issue may give an unbalanced view of the Court's approach since it is in this field that the Court applies the most 'sovereigntist' approach. In other situations, the Court has readily invoked international law norms as part of its reasoning. The next section turns to some recent cases where the Court has dealt with international law issues.

\subsection{Air Transport Association of America (ATAA)}

The case of Air Transport Association of America (ATAA) is helpful in demonstrating the CJEU's relationship within international law. It is not a ground-breaking case in terms of establishing new legal rules, but it does go a long way to clarify certain concepts regarding the way international law is dealt with by the CJEU. The case involves a challenge to a 2008 Directive that applied the EU's emission trading scheme (ETS) to aviation. ${ }^{47}$ Under the scheme, non-EU airlines would be subject to the EU's carbon trading scheme if they landed in or took off from an airport in the territory of an EU Member State. The Directive was challenged on the basis that it violated numerous international law principles established under

\footnotetext{
${ }^{46}$ A Alì, 'Some Reflections on the Principle of Consistent Interpretation Through the Case Law of the European Court of Justice International Courts and the Development of International Law, in N Boschiero, T Scovazzi, C Pitea \& C Ragni (eds), International Courts and the Development of International Law: Essays in Honour of Tullio Treves (2013) 882.

${ }^{47}$ Directive 2008/101/EC of the European Parliament and of the Council of 19 November 2008 Amending Directive 2003/87/EC so as to Include Aviation Activities in the Scheme for Greenhouse Gas Emission Allowance Trading within the Community [2008] OJ 2009 L 8/3.
} 
the Chicago Convention, ${ }^{48}$ the Open Skies Agreement, ${ }^{49}$ the Kyoto Protocol, ${ }^{50}$ as well as rules of customary international law. The ETS was established, in part, to implement the EU's obligations under the Kyoto Protocol in order to 'promote reductions of greenhouse gas emissions in a cost-effective and economically efficient manner. ${ }^{51}$ However, it was argued that the ETS applied 'extra-territorially' since it applied to the entire flight, not only to the part over EU airspace. It was also challenged on the basis of being a 'unilateral' measure, since the EU had taken the step without similar market-based mechanisms established at the international level, such as through ICAO. The third main argument was that the Directive breached international agreements liberalising the aviation industry, since it constituted a tax or charge on airlines.

The Court examined these issues in a methodical fashion, observing each international agreement in turn to see whether it was binding upon the Union and whether it could be used as a basis of review of EU acts. Regarding the Chicago Convention, the Court found that it was not binding upon the Union since the EU was not a party to the Convention, although all EU Member States were. The Court refused to apply the principle of functional succession to the convention since it could not be established that 'a full transfer of the powers previously exercised by the Member States to the Community ${ }^{52}$ had been established. Both the Kyoto Protocol and the Open Skies Agreement were found to be binding upon the Union.

In line with its case law on direct effect, the Court examined whether the 'nature and the broad logic' of the treaties in question precluded them from being used to challenge EU legislation. In addition, the Court examined whether the specific provisions of these treaties 'appear, as regards their content, to be unconditional and sufficiently precise so as to confer on persons subject to European Union law the right to rely thereon in legal proceedings in order to contest the legality of an act of European Union law. ${ }^{53}$ With regard to the Kyoto Protocol, the Court found that it could not be considered as unconditional

\footnotetext{
${ }^{48}$ Convention on International Civil Aviation, 7 December 1944, 15 UNTS 295 (Chicago Convention).

${ }^{49}$ US-EU Air Transport Agreement, 30 April 2007, 46 ILM 470.

${ }^{50}$ Kyoto Protocol to the United Nations Framework Convention on Climate Change, 11 December 1997, 2303 UNTS 148 (Kyoto Protocol).

${ }^{51}$ Directive 2003/87/EC of the European Parliament and of the Council of 13 October 2003 Establishing a Scheme for Greenhouse Gas Emission Allowance Trading within the Community and Amending Council Directive 96/61/EC [2003] OJ 2003 L 275/32.

${ }^{52}$ Case C-308/06, Intertanko [2008] ECR I-4057, para 49 (emphasis added).

${ }^{53}$ Case C-366/10, ATAA [2011] ECR I-1133, para 74.
} 
and sufficiently precise so as to confer on individuals the right to rely on it in order to contest the validity of the ETS Directive. This was due to the fact that Kyoto allows for 'a certain degree of flexibility in the implementation of their commitments. ${ }^{54}$ Regarding the Open Skies agreement, the Court found that the nature and broad logic of the agreement did not preclude it from being used to assess the validity of the contested Directive. ${ }^{55}$ It then turned to the language of the agreement to determine whether the provisions were 'unconditional and sufficiently precise' so as to allow for review.

The Court applies a different approach, however, where customary international law is concerned. In the case at hand, it stated that a principle of customary international law may be relied upon 'in so far as [...] those principles are capable of calling into question the competence of the European Union to adopt that act. $^{56}$ The second part of the test is that the EU act 'is liable to affect rights which the individual derives from European Union law or to create obligations under European Union law in his regard. ${ }^{57}$ The Court found that, while the principles of customary international law create obligations between States, in the present case the principles can also be relied upon by individuals to examine the validity of the Directive. ${ }^{58}$ However, the Court limits its judicial review to the question whether 'in adopting the act in question, the institutions of the European Union made manifest errors of assessment concerning the conditions for applying those principles. ${ }^{59}$ The Court therefore applies a substantially different test regarding direct effect depending on whether customary law or treaty law is invoked. This is because, according to the CJEU, customary international law 'does not have the same degree of precision as a provision of an international agreement. ${ }^{6}{ }^{60}$

The Court deals with international law in a straightforward, even rigid manner. The effect of the case is that despite its apparent openness towards international law, the CJEU applies rather restrictive rules to determine whether international law may be used to challenge EU legislation. The case received criticism, especially from air and space lawyers from outside the EU. It was

\footnotetext{
${ }^{54}$ Ibid, para 75 .

${ }^{55}$ Ibid, paras 79-84.

${ }^{56}$ Ibid, para 107. The Court cited the following case law supporting this test: Joined Cases 89/85, $104 / 85,114 / 85,116 / 85,117 / 85$ and 125/85 to 129/85 Ahlström Osakeyhtiö and Others v Commission [1988] ECR 5193, paras 14-8; Case C-405/92 Mondiet [1993] ECR I-6133, paras 11-6.

${ }^{57}$ Case C-366/10, ATAA [2011] ECR I-1133, para 107.

${ }^{58}$ Ibid, para 109.

${ }^{59}$ Ibid, para 110.

${ }^{60}$ Ibid.
} 
described as an example of the 'growing isolationism of the Court's case law'. ${ }^{61}$ Parts of the judgment have been described as 'rather short and cryptic' ${ }^{\prime 2}$ using 'fragile reasoning ${ }^{63}$ without a thorough engagement with the international legal issues at play. With regard to the non-applicability of the Chicago Convention, some commentators found it perplexing that 'the EU's highest court felt at liberty to discard international aviation law's foundational treaty as irrelevant to the most vexed international aviation dispute in recent memory. ${ }^{64}$ It also shows that the CJEU is not open to direct effect of international treaties unless they involve rights capable of being relied upon by individuals. In effect, this reduces direct effect of international agreements to trade agreements, association agreements, as well as partnership and cooperation agreements entered into by the Union. It precludes a range of multilateral agreements from being used as a standard of review since they are usually couched in broad terms giving the parties greater room to implement the agreement.

The ATAA case demonstrates the CJEU's more rigid approach to international law. It begins in an international law-friendly tone: 'Under Article 3(5) TEU, the European Union is to contribute to the strict observance and the development of international law. Consequently, when it adopts an act, it is bound to observe international law in its entirety. ${ }^{65}$ However, it progressively developed rules that limit the circumstances where international law may be given effect. Moreover, although the Court is open in principle to interpreting EU law 'in the light of' international law, in this case the Court did not endeavour to apply the principle of consistent interpretation. It is a prime example of the CJEU in its role as a domestic court, limiting the effect of international law when it is used to challenge EU acts.

\footnotetext{
${ }^{61}$ B Mayer, 'Case C-366/10, Air Transport Association of America and Others v Secretary of State for Energy and Climate Change' (2012) 49 CMLR 1135.

${ }^{62}$ E Denza, 'International Aviation and the EU Carbon Trading Scheme: Comment on the Air Transport Association of America Case' (2102) 7 European LR 323.

${ }^{63}$ Mayer, above n 61, 1139.

${ }^{64}$ B F Havel \& J Q Mulligan, 'The Triumph of Politics: Reflections on the Judgment of the Court of Justice of the European Union Validating the Inclusion of Non-EU Airlines in the Emissions Trading Scheme' (2012) 37 Air \& Space L 10.

${ }^{65}$ Case C-366/10, ATAA [2011] ECR I-1133, para 101.
} 


\subsection{Brita}

The Brita case has been presented as a case where the CJEU adopted a more international law friendly attitude. ${ }^{66}$ Brita, a German company, imported drink makers for sparkling water, accessories and syrups, from an Israeli supplier, Soda Club Ltd. The German authorities refused to give preferential treatment to Brita on the grounds that it could not be established conclusively that the imported goods fell within the scope of the EC-Israel Association Agreement. This is because Brita had stated that the goods' country of origin was Israel, although they were manufactured in Mishor Adumin in the West Bank, East of Jerusalem. The question was whether the goods should have been given preferential treatment in any event, since they would have fallen under the EC-Israel Association Agreement or EC-PLO Association Agreement.

The Court made use of rules laid down in the 1969 Vienna Convention on the Law of Treaties to the extent that they represent customary international law, which is binding on the European Union. The CJEU held that 'the rules laid down in the Vienna Convention apply to an agreement concluded between a state and an international organisation [...] in so far as the rules are an expression of general international customary law. ${ }^{67}$ One of these rules that the Court sought recourse to was the general international law principle of the relative effect of treaties, according to which treaties do not impose any obligations or confer any rights on third states (pacta tertiis nec nocent nec prosunt). The Court therefore interpreted Article 83 of the EC-Israel Association Agreement, which defines the territorial scope of that agreement, in a manner that is consistent with that principle of international law. The CJEU considered that if it were to interpret Article 83 in a way that the Israeli customs authorities enjoy competence in respect of products originating in the West Bank, this would be tantamount to imposing on the Palestinian customs authorities an obligation to refrain from exercising the competence conferred upon them by virtue of the EC-PLO Protocol. Such an interpretation, the Court found, would create an obligation for a third party without its consent, and would thus be contrary to the pacta tertiis nec nocent nec prosunt principle.

The case can be seen as another example of the CJEU applying international law, as Klabbers states, 'in ways which are all but unrecognizable to the international lawyer. ${ }^{68}$ Klabbers was referring in that instance to the way in which the

\footnotetext{
${ }^{66}$ C-386/08, Brita GmbH v Hauptzollamt Hamburg-Hafen [2010] ECR I-1289, para 41 (Brita).

${ }^{67}$ C-386/08, Brita [2010] ECR I-1289, para 41.

${ }^{68}$ Klabbers, above n 12, 72 .
} 
CJEU applied the rebus sic stantibus rule in the Racke case. ${ }^{69}$ Similarly in Brita, the CJEU applied the pacta tertiis nec nocent nec prosunt principle in order to interpret the treaty, arguably in a way that would be peculiar to some international lawyers. Although the Court had employed the 1969 VCLT in previous case law, this had involved Article 31 thereof which are the rules pertaining to the general rules of treaty interpretation. ${ }^{70}$ Article 34 VCLT, however, is not a rule of treaty interpretation but a principle that a treaty does not create either obligations or rights for a third State without its consent. Hence, although the CJEU applied international law in this case, it arguably did so in a somewhat novel way.

Moreover, the case is silent on the wider international law context of the case. The Opinion of the Advocate General makes references to the wider context of the Israel-Palestine dispute, including references to United Nations Security Council Resolution 242, ${ }^{71}$ which calls upon Israel to withdraw from the occupied territories. The judgment, however, makes little reference to the wider context of the dispute. The Court is able to avoid discussion of this wider context, however, by treating the case very much similar to a standard customs cooperation case. Yet, the case is more than a straightforward customs case and the Court is faced with delicate issues of international law. While the case may be presented as one where the Court shows an open attitude to international law, it is in reality one where the CJEU has made use of international law as a tool in its reasoning. International law was not being used to challenge an act of the EU but to help resolve a dispute involving EU law.

\subsection{Hungary v Slovakia}

The recent Hungary $v$ Slovakia $^{72}$ case can be seen as an example of the Court acting as more of an 'international court'. The case relates to a diplomatic incident between Hungary and Slovakia in which the President of Hungary, Mr László Sólyom was scheduled to go to the Slovak town of Komárno in order to inaugurate a statue of Saint Stephen, the founder and first king of Hungary. Slovakian authorities refused to allow entry of the Hungarian President, considering the visit to be a provocation. Hungarian authorities argued that the measure that had prohibited Mr Sólyom from entering Slovak territory

\footnotetext{
${ }^{69}$ Case C-162/96, Racke [1998] ECR I-3655.

${ }^{70}$ See P J Kuijper, 'Case C-386/08, Brita GmbH v Hauptzollamt Hamburg-Hafen Judgment of the European Court of Justice of 25 February 2010' (2010) 37 Legal Issues of Economic Integration 241.

${ }^{71}$ SC Res 242, 22 November 1967.

${ }^{72}$ Case C-364/10, Hungary v Slovak Republic [2012] nyr.
} 
was in breach of EU law. Hungary instituted proceedings against Slovakia under the procedure in Art 259 TFEU. ${ }^{73}$ This was only the fourth time a Member State had made use of this procedure.

The Court held that as a Hungarian national Mr Sólyom enjoys European citizenship and the rights associated with it including the right to move and reside freely within the territory of the Member States as set out in Art 21 TFEU.74 However, the status of a Head of State in international law constitutes a limitation on the application of the Union's right of free movement. It found that EU law does not oblige Slovakia to grant access to its territory to the President of Hungary. In doing so, it examined principles of customary international relating to visits by Heads of State.

In deciding how to resolve the diplomatic row, the Court had a number of options. The first option would be to stress the primacy of EU law and to find that the incident can be solved with reference solely to the EU law of free movement of persons. The other option was to find that EU law does not apply in this case and therefore look to the application of international law, especially the international law of diplomatic relations. In effect, the second option would mean the restriction of certain rights of EU nationals, in this case the President of Hungary, based on international law. Rather, the CJEU sought to follow a third option, to interpret relevant EU law 'in the light of' international law.

The case can be seen as another example of the CJEU being 'open' to international law. However, the way in which the Court engages with international law questions is again novel. While it referred to customary international law regarding the status of Heads of State, it did not go on to identify what the content of these rules actually were. Interestingly, the Court did not look towards the case law of other regional or international courts that had faced similar issues, such as the ICJ's judgment in the Arrest Warrant case. ${ }^{75}$ The Court employs international law, but in a way that many international lawyers may find puzzling.

The case has also been presented as a move away from the strictly 'dualist' reasoning that underpinned the Kadi judgment: 'While the scope of Hungary

\footnotetext{
${ }^{73}$ Consolidated Version of the Treaty on the Functioning of the European Union [2012] OJ C 326/47 (TFEU) Art 259: 'A Member State which considers that another Member State has failed to fulfill an obligation under the Treaties may bring the matter before the Court of Justice of the European Union'.

${ }^{74}$ TFEU Art 21: 'Every citizen of the Union shall have the right to move and reside freely within the territory of the Member States, subject to the limitations and conditions laid down in the Treaties and by the measures adopted to give them effect'.

${ }^{75}$ Arrest Warrant of 11 April 2000 (Democratic Republic of the Congo v Belgium), ICJ Reports 2002 p 3.
} 
is unclear and the case may prove to be a context specific exception to the ECJ's otherwise dualist approach, it might instead suggest a broader role for international law within the EU than it had previously been thought. ${ }^{76}$ One could imagine the Court employing Kadi style reasoning to assert the primacy of rules of free movement in the same way it stressed the primacy of fundamental rights. Rather, the Court's judgment should be seen as an astute attempt to avoid a clash between EU and international law as in Kadi. It continued to assert the fundamental character of citizenship in EU law but interpreted it with reference to applicable customary international law. One analysis of the judgment states that "[a]s the European Union is also part of the greater international community, the CJEU recognised the precedence of international law over EU law, because international law is considered as part of the legal order of the EU and therefore is binding for all institutions.' ${ }^{77}$ But the Court did not really find that international law takes precedence over EU law, or that EU law did not apply to the situation. The Court asserted that EU law continues to apply but it should be read in the light of applicable international law rules. Again, international law is not being used to challenge an EU act but is used by the Court to resolve a dispute between EU Member States.

\subsection{Diakité}

To what extent should the CJEU interpret EU legislation in conformity with international law? This was one of the questions that was examined in the recent Diakité case. ${ }^{78}$ The key question in this case was whether the definition of 'internal armed conflict' is to be based on the criteria established by international humanitarian law or whether it can be given a separate, autonomous meaning for the purposes of European law. Specifically, the Court was asked to interpret the term 'internal armed conflict' used in Article 15(c) of Directive 2004/83/EC, which sets out minimum standards for granting refugee status or subsidiary protection status. ${ }^{79}$ The referring Court, the Belgian Conseil d'État, asked whether

\footnotetext{
76 'Case C-364/10, Hungary v Slovak Republic, 2012 ECJ EUR-Lex LEXIS' (2013) 126 Harvard LR 2425,2430 .

${ }^{77}$ M Filippin 'A Change for Future Intra-European Diplomatic Relations? Case C-364/10 Hungary v Slovakia, Judgment of 16 October 2012, not yet reported' (2013) 20 Maastricht JECL 120, 126.

${ }^{78}$ Case C-285/12, Aboubacar Diakité v Commissaire Général aux Réfugiés et aux Apatrides [2014] nyr (Diakité).

${ }^{79}$ Council Directive 2004/83/EC of 29 April 2004 on minimum standards for the qualification and status of third country nationals or stateless persons as refugees or as persons who otherwise need international protection and the content of the protection granted [2004] OJ L 304/12.
} 
the terms should be defined according to international humanitarian law, in particular with reference to Common Article 3 of the four Geneva Conventions of 12 August 1949.

In his Opinion, ${ }^{80}$ Advocate General Mengozzi referred to Article 3(5) TEU, which states that the EU shall contribute to the 'strict observance and the development of international law strict observance and the development of international law. ${ }^{81}$ Based on this article, as well as relevant case law, it was noted that EU measures should be interpreted in the light of relevant rules of international law. This includes not only treaties binding upon the Union, but also customary international law. However, he noted that the term internal armed conflict' in the Directive is used for a different purpose than that of 'non-international armed conflict' in IHL. The Court followed this reasoning, stating that the terms relate to two different fields of law, both of which have different aims and involve different protection regimes. ${ }^{82}$

Since the Directive itself does not define the term 'internal armed conflict', the Court interpreted the term according to its usual meaning in everyday language, taking into account the purposes of the legislation. ${ }^{83}$ The Court then defined the term 'internal armed conflict' as 'a situation in which a State's armed forces confront one or more armed groups or in which two or more armed groups confront each other. ${ }^{84}$ Under international humanitarian law, specifically Common Article 3, for hostilities to be considered as 'a conflict of a non-international character' they must meet specific criteria. The hostilities must have reached a certain threshold of intensity, setting them apart from isolated and sporadic acts of violence or banditry, and the hostilities must involve non-governmental forces that have some kind of organised command structure. The Court therefore established a much broader definition of the term for the purposes of EU law. The Court justifies the separate definitions on the basis that international humanitarian law and the relevant EU Directive were designed for different purposes and spheres of application.

This can be viewed as the CJEU finding an autonomous, 'European' meaning to a term that is already defined by international law, and an example of the 'fragmentation' of international law. In this way, it is reminiscent of the divergence between the International Court of Justice and the Appeals Chamber

\footnotetext{
${ }^{80}$ Case C-285/12, Diakité [2014] nyr, Opinion of Advocate General Mengozzi.

${ }^{81}$ TEU Art 3(5).

${ }^{82}$ Case C-285/12, Diakité [2014] nyr, para 24.

${ }^{83}$ Ibid, para 27.

${ }^{84}$ Ibid, para 28.
} 
of the International Criminal Tribunal for the former Yugoslavia concerning the test to determine the nature of an armed conflict. The ICTY Appeals Chamber in applying an 'overall control' test, seemed to deviate from the 'effective control' test applied by the ICJ in the Nicaragua judgment. ${ }^{85}$ However, this apparent divergence can be explained by the fact that the ICJ and ICTY Appeals Chamber were applying these tests in different legal contexts. In Tadic, the Appeals Chamber was determining whether or not an armed conflict exists for the purpose of determining whether the grave breaches system would apply. ${ }^{86}$ In Nicaragua, however, the ICJ was primarily concerned with the topic of state responsibility, not individual criminal law. In the Bosnia Genocide case, the ICJ rejected the notion that a single test had to apply to both bodies of law:

[T] he degree and nature of a State's involvement in an armed conflict on another State's territory which is required for the conflict to be characterized as international, can very well, and without logical inconsistency, differ from the degree and nature of involvement required to give rise to that State's responsibility for a specific act committed in the course of the conflict. ${ }^{87}$

Likewise, the definition of internal armed conflict for the purposes of EU legislation can require a lower level of intensity and organisation of armed groups than that required by IHL.

Although the CJEU applied a different definition in this case, its approach in Diakité is not antagonistic towards international law. The situation would be different, however, if the EU Directive had intended to implement an international legal obligation. In such a case, it is likely that the Court would be more inclined to apply the definition used at the international level. However, this stems from an obligation under EU law, especially Article 3(5) TEU and not out of respect for international law per se.

\footnotetext{
${ }^{85}$ Military and Paramilitary Activities In and Against Nicaragua (Nicaragua v US), ICJ Reports $1986 \mathrm{p}$ $14,65$.

${ }^{86}$ Prosecutor v Dusko Tadić (aka 'Dule'), Appeals Chamber, Case No IT-94-1-A, 1999, 1.

${ }^{87}$ Application of the Convention on the Prevention and Punishment of the Crime of Genocide (Bosnia and Herzegovina $v$ Serbia and Montenegro), ICJ Reports 2007 p 43, 210.
} 


\section{Conclusion: International or Domestic Court?}

The case of Van Gend en Loos is often cited as the point where the Court marked the beginning of its liberation from international law when it declared that 'the Community constitutes a new legal order of international law. ${ }^{88}$ The story is that the EU, founded by international instruments, soon developed its own legal order and 'broke free' from international law: '[t]he European treaties have, of course, been concluded according to the rules of international law. But the legal order which was erected soon emancipated from its origins'. ${ }^{89}$ While international law has little relevance in interpreting and applying the EU treaties, the EU very much remains bound by international law in its relationship with the outside world. The idea is that the EU legal order 'broken free' from international law is only one part of a much more complex reality. International law still applies to the EU as an international actor. The CJEU still employs international law in its judicial reasoning and seeks to apply EU law in the light of international law.

Much of the literature on the CJEU's relationship with international law has focused on the landmark Kadi judgment. The judgment was criticised by many international lawyers, who argued that it was an example of the CJEU turning towards a more 'dualist' approach:

The ECJ's reasoning was robustly dualist, emphasizing repeatedly the separateness and autonomy of the EC from other legal systems and from the international legal order more generally, and the priority to be given to the EC's own fundamental rules. A related and significant feature was the lack of direct engagement by the Court with the nature and significance of the international rules at issue in the case, or with other relevant sources of international law. ${ }^{90}$

It is true that the judgment seems to lack a thorough engagement with international law issues. The Charter of the United Nations is viewed as nothing more than a mere international agreement, and the Court did not fully discuss the application of Art 109 of the Charter, which sets out the supremacy of

\footnotetext{
${ }^{88}$ Case C-26/62, Van Gend en Loos [1963] ECR 1.

${ }^{89}$ K-M Meessen, 'The Application of Public International Law Within Community Law' (1976) 13 CMLR 485, 485.

${ }^{90} \mathrm{G}$ de Búrca, 'The European Court of Justice and the International Legal Order After Kadi' (2010) 51 Harvard ILJ 1, 23.
} 
Charter obligations in the event of conflict. ${ }^{91}$ This one case, however, cannot be considered representative of the CJEU's approach towards international law in general. It is a rather extreme case where the CJEU acted 'as any other "constitutional court of a municipal legal order". 92 The case has been discussed in depth elsewhere from numerous angles. The point to be made here is that in Kadi the Court felt the need to safeguard its autonomy from the international legal order, something that was all the more important since it involved fundamental human rights norms enshrined in EU primary law. In doing so, the Court was not placing EU law above international law, nor was it asserting the separateness of the EU legal order from international law. By focusing on this case, international lawyers may view the CJEU adopting a sovereignist approach, one which poses a serious challenge to the integrity of the international legal order and the UN system.

Yet, there are still instances where the Court's approach is that of an international court, one which is open to international law influences in resolving legal disputes. Recent cases such as Diakité or Hungary $v$ Slovakia are examples of the Court playing this role. The Court is after all a court of a regional international organisation and its judgments are highly influential in the development of international law. Some may assume that this means that the Court should be more open towards international law since international law is in the DNA of the EU. Yet, the Court's approach can be viewed as an outcome of the constitutionalisation of both the EU and the international legal orders. The Court is still trying to find a balance between protecting the autonomy of its own legal order and the openness towards international law that is enshrined in the EU Treaties. Rather than view the CJEU's approach to international law as 'open' or 'closed', it should be understood as involving multiple relationships depending on the way in which international law norms come before the Court.

\footnotetext{
${ }^{91}$ Charter of the United Nations, Art 109 (UN Charter): 'In the event of a conflict between the obligations of the Members of the United Nations under the present Charter and their obligations under any other international agreement, their obligations under the present Charter shall prevail'.

${ }^{92}$ V Fikfak, 'Kadi and the Role of the Court of Justice of the European Union in the International Legal Order' (2013) 15 CYELS 21.
} 